Arch. histol. jap., Vol. 41, No. 5 (1978)

p. $439-451$

Department of Anatomy (Profs. N. Simizu and I. Nagatsu),

Fujita-Gakuen University School of Medicine,

Aichi, Japan

\title{
Early Changes in the Structure of Rat Sciatic Nerves by Ligation
}

\author{
Ikuko Nagatsu, Nobuyuki Karasawa and Nobuo Shimizu
}

Received April 12, 1978

\begin{abstract}
Summary. In order to find any morphological changes that might occur in the accumulation of catecholamine synthesizing enzymes following ligation of the sciatic nerve, light and electron microscopic studies were made in segments both proximal and distal to the ligature of the rat sciatic nerve from the initial period up to 4 days. The earliest changes were observed in the larger myelinated nerve fibers at 0.5 and $1.0 \mathrm{~mm}$ segments distal and proximal to the ligature, while little if any changes occurred in smaller myelinated nerve fibers. The non-myelinated fibers showed an increased electron density of axons due to the increase in density of the matrix, increased numbers of microtubules and/or microfibriles and of vesicles and vacuoles of varying size in addition to the enlarged size of the axon. These types of changes in the non-myelinated fibers seem to be more marked in the proximal segments, and are probably responsible for the accumulation of axoplasm containing some enzymes.
\end{abstract}

It has been reported that the catecholamine synthesizing enzymes, such as tyrosine hydroxylase and dopamine $\beta$-hydroxylase are accumulated at the ligature 1 and 2 days after ligation of sciatic nerves, as shown by immunofluorescence of tyrosine hydroxylase (NAGATSU et al., 1977) and dopamine $\beta$-hydroxylase (NAGATsu et al., 1974) and by biochemical measurements of enzyme activities (NAGATSU and Kondo, 1975).

On the other hand, it seems necessary to investigate a relation between the morphological changes of the sciatic nerves due to ligation and the accumulation of catecholamine synthesizing enzymes and also catecholamines. Though the catecholamine fibers belong to the non-myelinated fibers, the sciatic nerve of rats contains small numbers of amine fibers dispersed among the main constituents composed of the myelinated fibers (DAhlström, 1965; Olson, 1969; etc.). In the present experiment the early morphological changes of both myelinated and non-myelinated nerve fibers were examined 1 to 4 or 5 days following ligation under the light and electron microscope.

\section{Materials and Methods}

Wistar rats (200-250 g) were used for the experiments. The ligation of the sciatic nerve was performed with $4-0$ surgical silk (left in situ) at the level of about $1 \mathrm{~cm}$ below the foramen infrapiriforme (DAHLsTRöM, 1965) under light ether anaesthesia, and proximal and distal segments to the ligature were removed at 1,2 and 4 or 5 days following ligation (Fig. 1).

For degeneration silver method, segments of the sciatic nerves were fixed with $10 \%$ formalin and $20 \mu$ frozen sections were cut longitudinally and stained by NAUTA- 


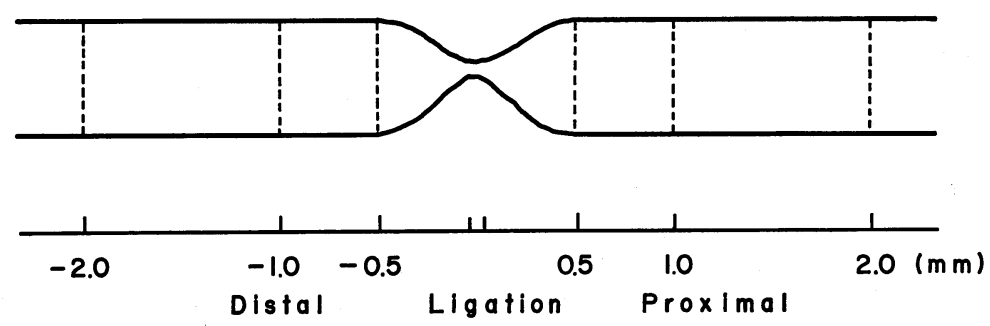

Fig. 1. Diagram to show the segments of sciatic nerves, proximal and distal to the ligation.

Gygax (1954) and FinK-Heimer (1967) methods.

For electron microscopy, segments of the sciatic nerve were fixed with $4 \%$ paraformaldehyde- $2.5 \%$ glutaraldehyde mixture and postosmicated and embedded in epon. One $\mu$ cross sections taken from each segment were observed for myelinated nerve fibers under a light microscope, and adjacent ultrathin sections were observed for both myelinated and non-myelinated nerve fibers by a Hitachi HU-12 electron microscope. Both light and electron microscopic observations were made at the segments 0.5, 1.0 and $2.0 \mathrm{~mm}$ proximal and distal to the ligature (Fig. 1).

\section{Observations}

\section{A. Light Microscopic Observations}

\section{Degeneration silver methods}

The NAutA-Gygax method (Fig. 2A) showed that coarse granular argyrophilic materials (arrows) were accumulated irregularly in the myelinated fibers up to $2 \mathrm{~mm}$ proximal and distal to the ligature 1 day after ligation. Such proximal changes reached up to $3 \mathrm{~mm}$ proximally between 2 and 4 days after ligation. Similar changes were observed up to $6 \mathrm{~mm}$ distally between 2 and 4 days.

Using the FINK-HEIMER method (Fig. 2B), fine granular materials were seen in some myelinated fibers (arrows). The distances of changes in myelinated nerve fibers at proximal and distal segments of ligated sciatic nerves were almost the same as those observed by the NAUTA-GyGax method.

The morphological changes of non-myelinated fibers were not demonstrated by either method in the time up to 4 or 5 days following ligation.

\section{Observation in glutaraldehyde-osmium fixed epon embedded materials}

Under a light microscope, cross sections at each segment were observed and photographed, and myelinated fibers were examined for their integrity (Fig. 3A, B). The fibers were divided into 3 sizes: small-size, $1-5 \mu$, medium-size, $5-10 \mu$, and largesize, $10-15 \mu$. (The diameter of myelinated fibers of a normal sciatic nerve ranged from 1 to $10 \mu$ ). The morphological changes were classified into 3 categories (Fig. $3 \mathrm{~A}, \mathrm{~B})$ : normal fibers appeared as a round ring of darkly stained myelin, slightly changed fibers appeared as a slightly deformed ring with small inward protrusion of myelin, and marked changes were expressed by a dark staining of the entire fiber and disappearance of the axon. The myelinated fibers at each segment were clas- 
sified according to their morphological changes and size ranges (Fig. 4).

In Figure 4, the morphological changes at each survival time are demonstrated. At 1 day, medium-size and large-size fibers definitely showed morphological changes at distances 0.5 and $1.0 \mathrm{~mm}$ from the ligature, while small fibers showed hardly any

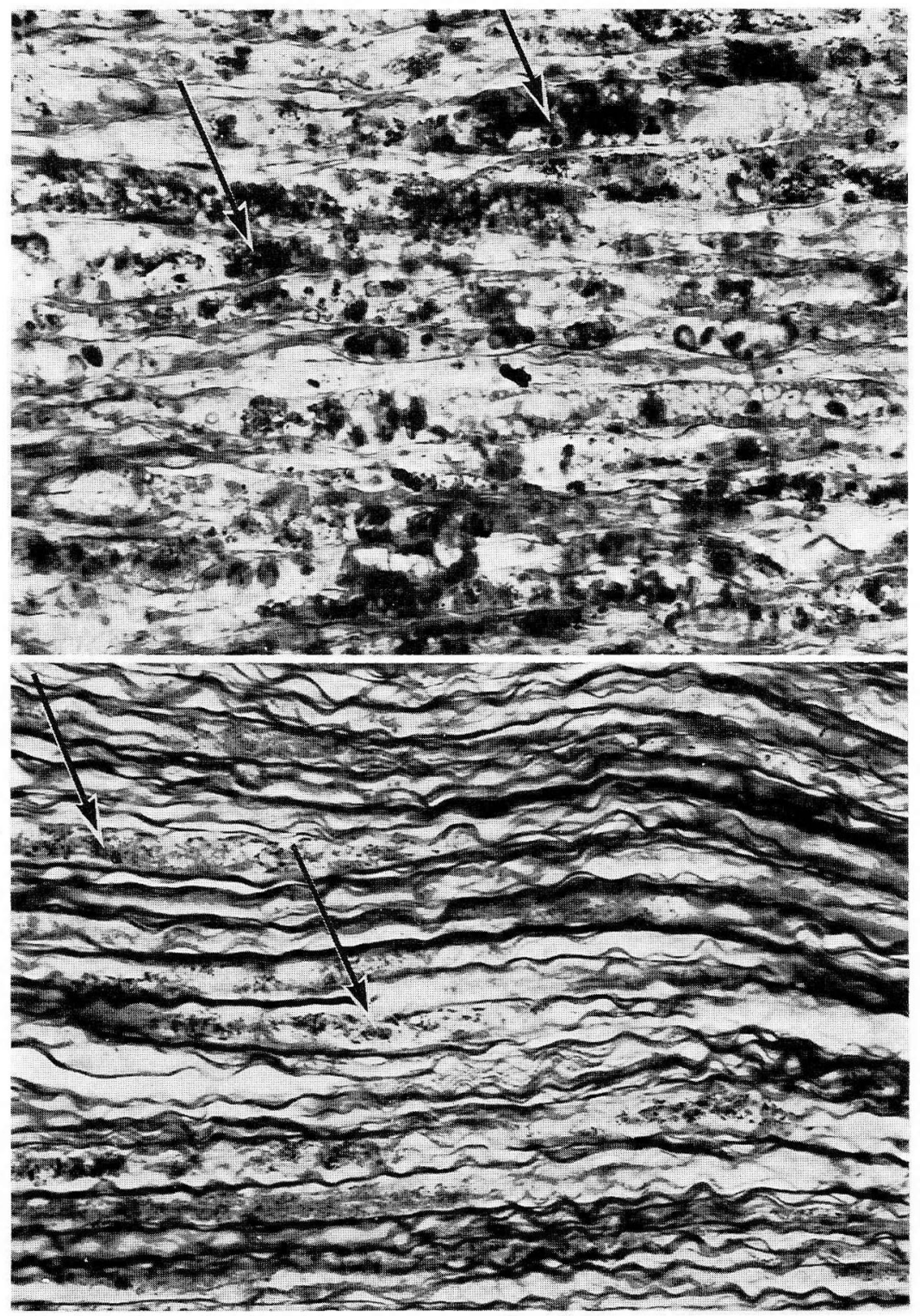

Fig. 2. Light micrographs of a longitudinal section of a sciatic nerve at $0.5 \mathrm{~mm}$ distal to a ligature at 2 days. A. Coarse granular argyrophilic materials (arrows) occur in nearly all of the large-sized fibers. NAUtA-Gygax stain. $\times 400$. B. Fine argyrophilic granules are shown in slightly enlarged large fibers (arrows). Fink-Heimer stain. $\times 400$ 


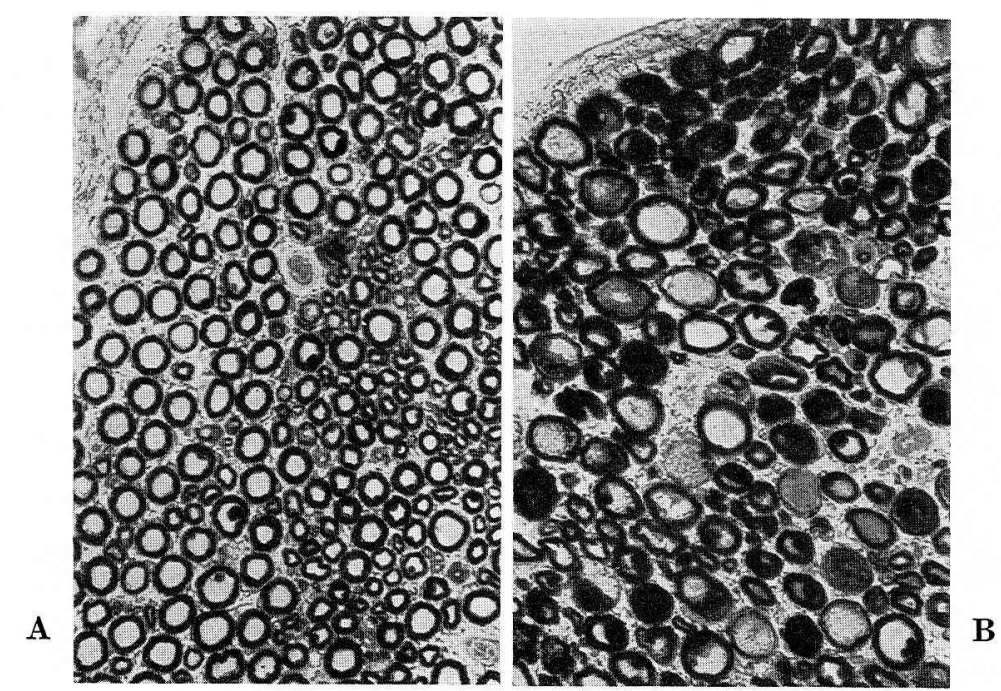

Fig. 3. Light micrographs of a cross section of a sciatic nerve of normal control (A) and of the segment $1 \mathrm{~mm}$ distal to the ligature at 1 day (B). Glutaraldehyde-osmium fixation, $1 \mu$ epon section. $\times 240$

changes. Two days after ligation the changes continued up to $2 \mathrm{~mm}$. At 4 days the changes became more marked in the medium-size and large-size fibers, and continued longer than $2 \mathrm{~mm}$ in the distal segment to the ligature. At 2 to 4 days, small fibers exhibited small numbers of marked changes at each segment.

Though bundles of non-myelinated fibers were observed among the myelinated fibers, they did not show any discernible changes under a light microscope.

\section{B. Electron Microscopic Observations}

\section{Myelinated fibers}

The morphological changes of the myelinated fibers in the present experimental condition showed highly different patterns. They are: 1) irregularly deformed myelin sheaths and frequent inward protrusion; 2) loosening, exfoliation and irregular globules or onion-shell like structure of myelin lamellae; 3) complete or partial disappearance of axoplasm; 4) dense accumulation of different kinds of organelles and debris in the axoplasm or an empty appearance; and 5) hypertrophied Schwann's cytoplasm. One day following ligation increased density of the axoplasm due to accumulation of cell organelles and debris was prominent (Fig. 5A, B, 8B), while at 2 days loosening and exfoliation of myelin lamellae or empty axoplasm became evident (Fig. 6A, B).

\section{Non-myelinated fibers}

Non-myelinated fibers of the normal sciatic nerve (Fig. 7) appeared as bundles of several round or oval axons enveloped within the cytoplasm of the Schwann cells. The axoplasm exhibited a relatively clear matrix containing a moderate number of longitudinally arranged neurotubules and/or filaments and a few vesicles and mitochondria. 
Following the ligation, the diameter of most fibers was moderately increased and morphological changes were definitely observed. In the proximal segment at 1 day (Fig. 8A), the axoplasm was increased in density probably due to increased density of matrix, increased numbers of neurotubules and/or neurofilaments coursing irregularly, and vesicles and vacuoles of varying size and shape. However, we could not find any granulated vesicles. Mitochondria seemed to increase in number and size.

\section{Rat sciatic nerve myelinated nerve}
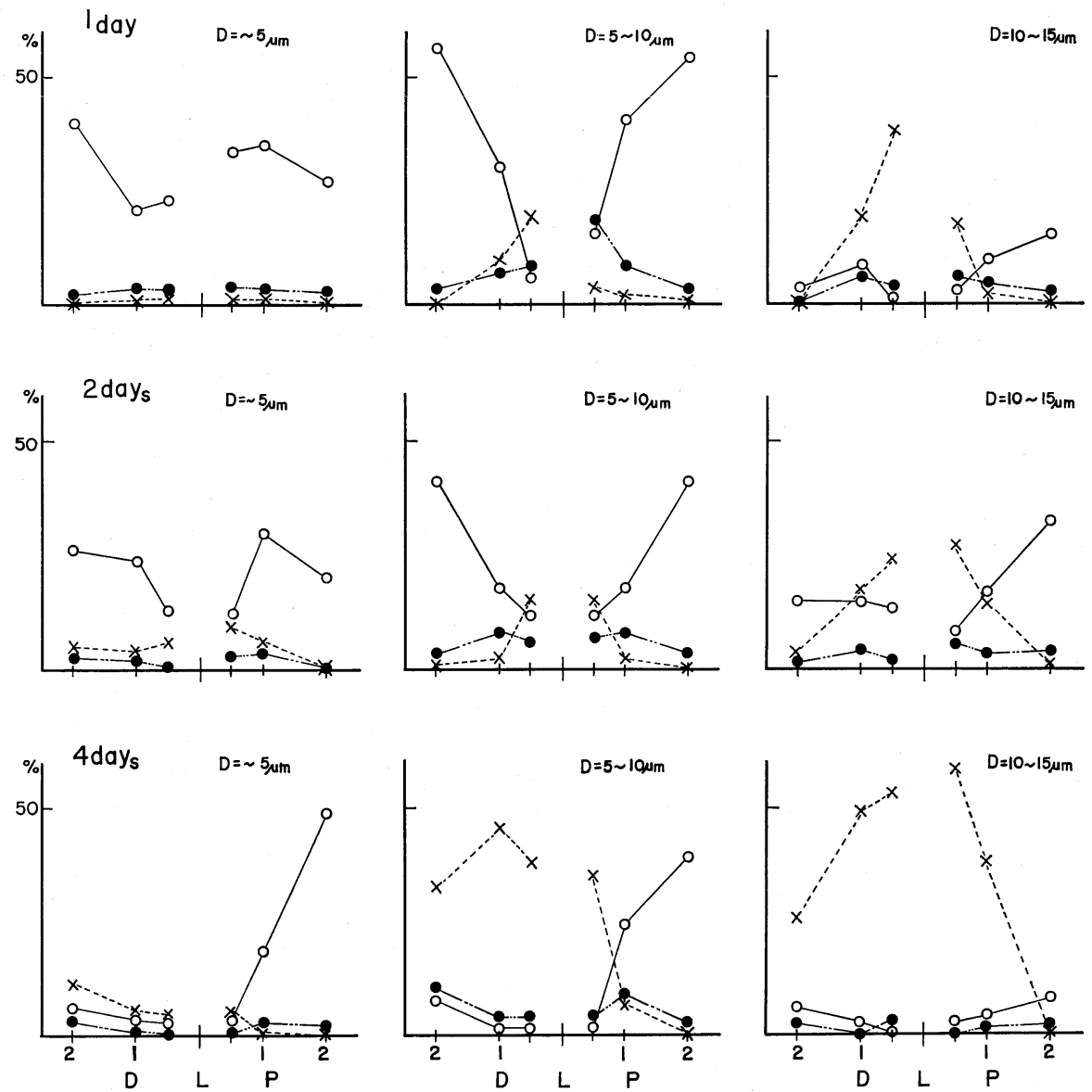

Fig. 4. Percentages of 3 types of morphological changes of myelinated fibers at each segment of sciatic nerves. All figures are arranged according to 3 size classes and 3 survival times. 


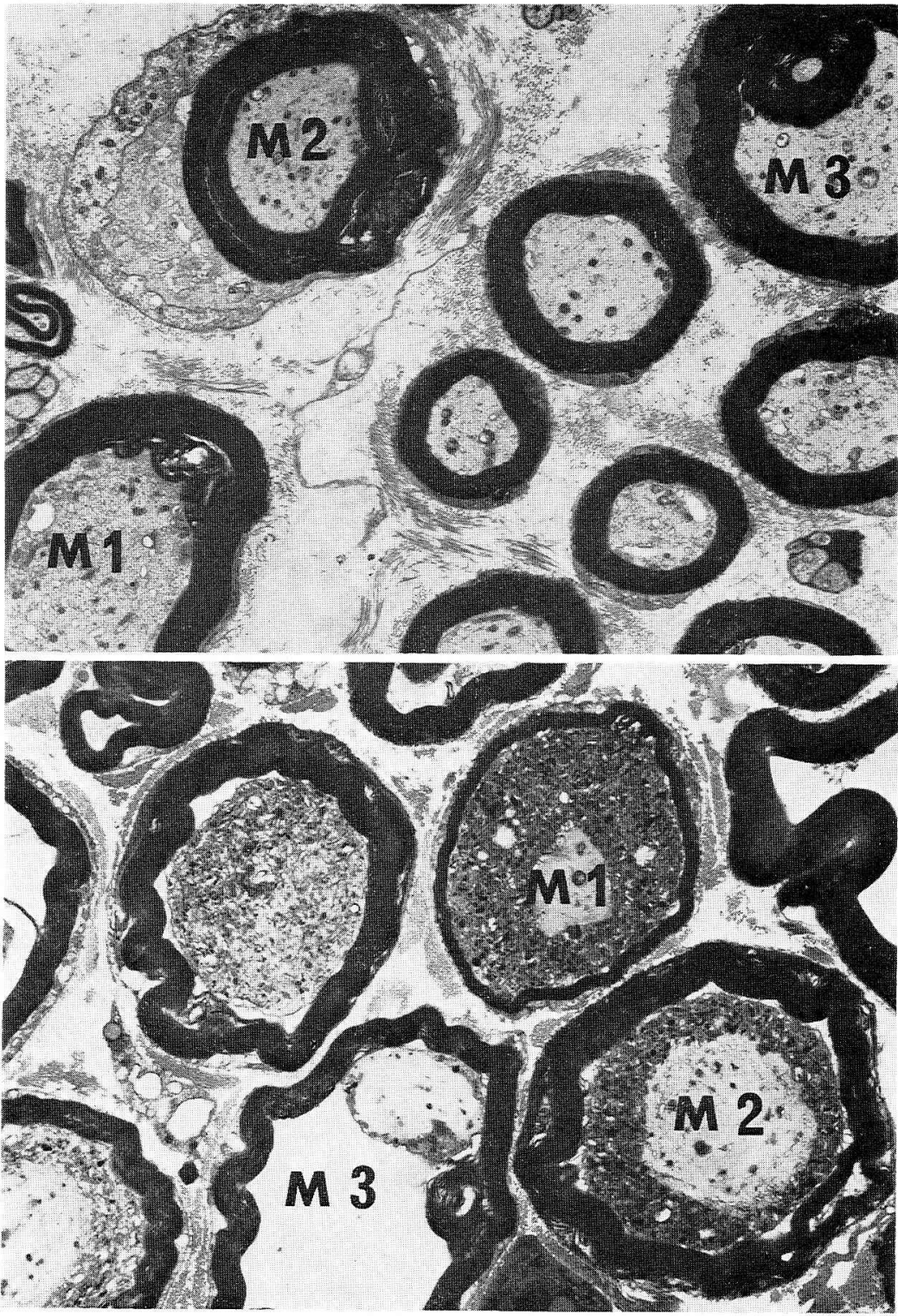

Fig. 5. Electron micrographs at segments $1 \mathrm{~mm}$ proximal (A) and distal (B) to a ligature, 1 day following ligation. A. Myelin sheath of 3 large fibers $(M 1, M 2, M 3)$ shows loosening, thickening or inward protrusion, axoplasm becomes slightly darker and condensed. Schwann cell cytoplasm of onelarge fiber (M2) is moderately enlarged. $\times 3,000$. B. Myelin sheath shows irregular outline, axoplasm exhibits darker zone containing various kinds of organelles and clear central portion (M1, M2), or empty spaces $(M 3) . \quad \times 3,000$ 


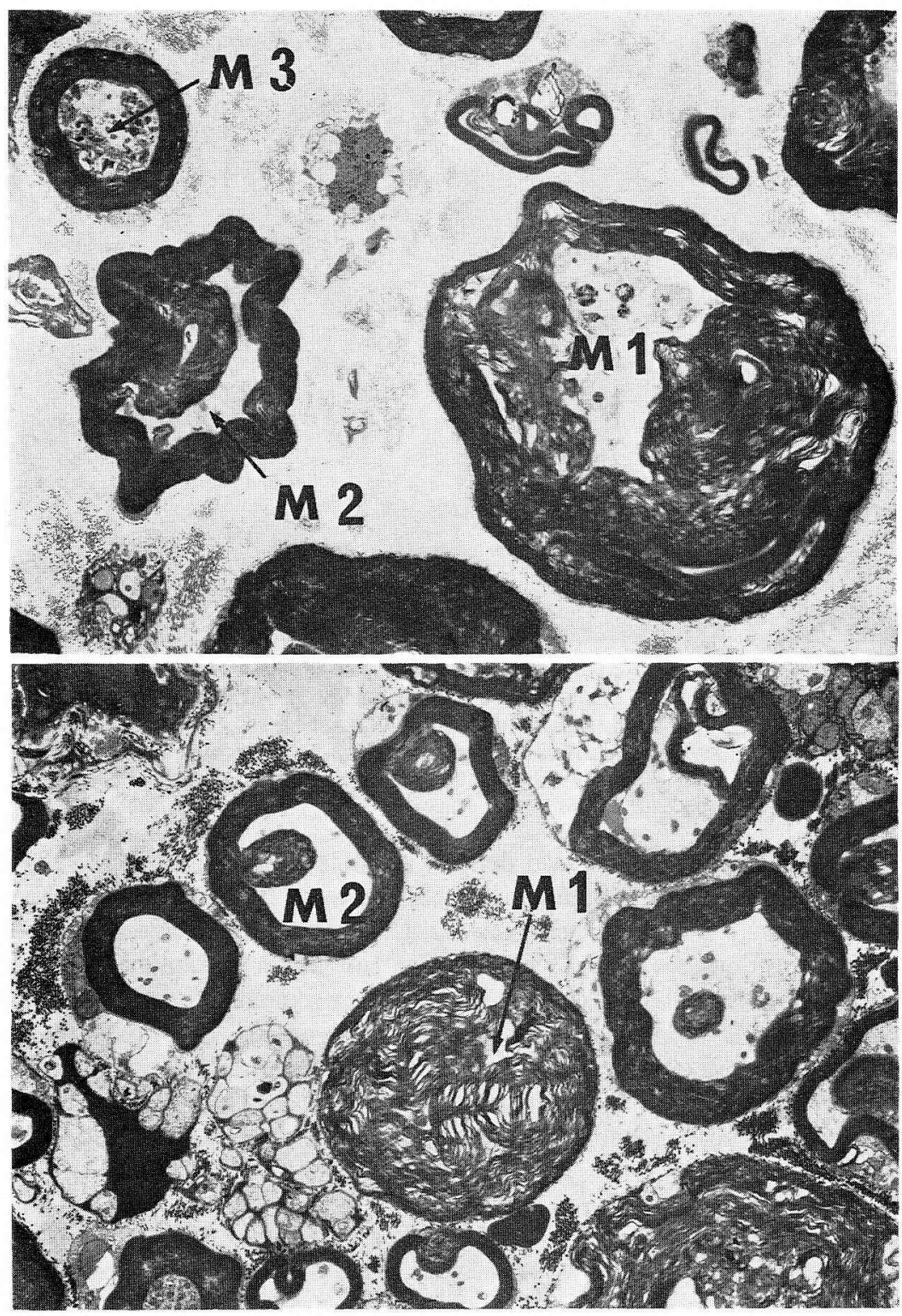

Fig. 6. Electron micrographs at segments $1 \mathrm{~mm}$ proximal (A) and distal (B) to a ligature, 2 days. A. Large myelinated fiber (M1) shows marked changes; irregular outline of myelin sheath, loosening exfoliated myelin lamellae, and decreased amount of axoplasm with a few organelles and clear matrix. Medium-sized fiber shows irregularly infolded contour (M2), or contains densely accumulated organelles $(M 3)$. $\times 3,000$. B. Large myelinated fiber (M1) shows onion-shell like structure devoid of axoplasm, and medium-sized fiber (M2) exhibits small protrusion of myelin sheath, with axoplasm of decreased electron density. $\times 3,000$ 


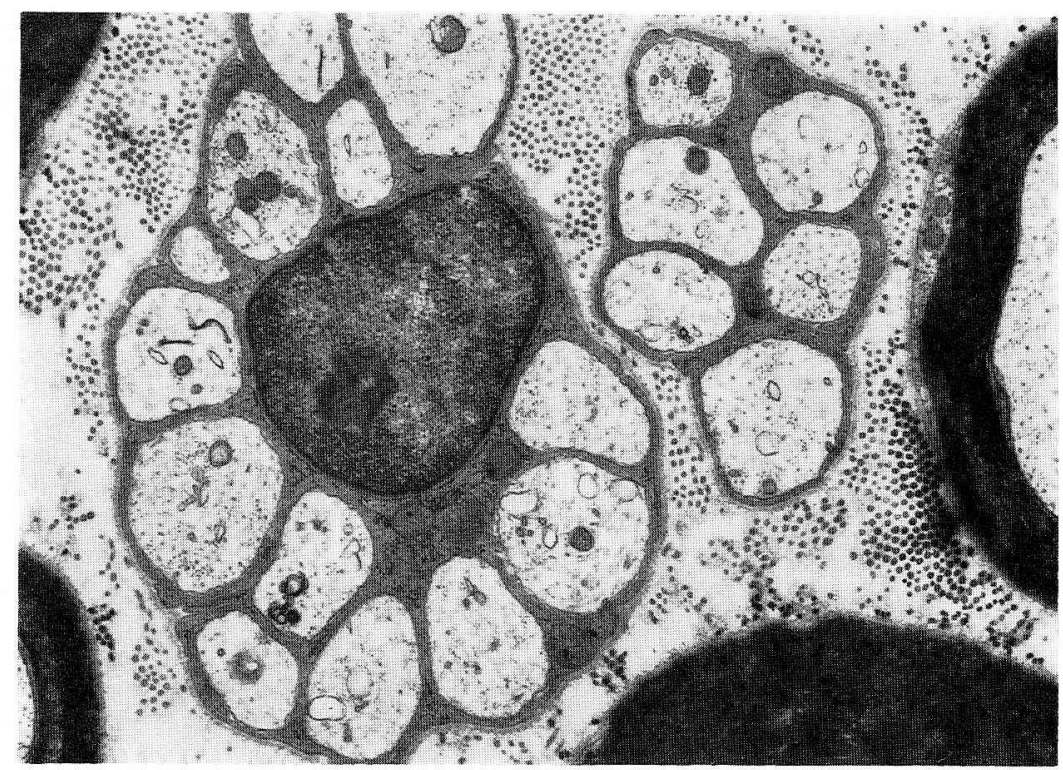

Fig. 7. Electron micrograph of two bundles of non-myelinated fibers in normal sciatic nerve. Both bundles are enveloped by Schwann cell cytoplasm of moderate density. Axons of non-myelinated fibers contain a few or no mitochondria, regularly arranged longitudinal microtubules and/or microfilaments, vesicles or vacuoles of varying size and axoplasmic matrix of low density. $\times 15,000$

The Schwann cells showed increased density of their cytoplasm. In the distal segment at 1 day (Fig. 8B), the morphological changes were slightly different from those in the proximal one. The axoplasm showed a highly different size and shape, with slightly increased density of matrix, irregular tubular or vesicular structures and enlarged mitochondria. At 2 days the changes of the axoplasm became more marked both in the proximal (Fig. 9A) and distal (Fig. 9B) segments. At 4 days the changes seemed to advance in intensity, showing the complicated and less evident boundaries of the axoplasm especially in the proximal segments. In this electron microscopic study we could not differentiate the catecholamine fibers in normal and constricted nerves.

\section{Discussion}

The Wallerian degeneration of both myelinated and non-myelinated nerves has been studied under the electron microscope by many investigators (HonJIN and Nakamura 1959; Ohmi, 1961; Nathaniel and Pease, 1963; Lee, 1963; Blümcke and Rode, 1966; O'DALy and IMAEDA, 1967; etc.). It is generally agreed that the axons exhibit degenerative changes earlier than the myelin sheath, but the susceptibility to degeneration according to fiber size and proximo-distal propagation or simultaneous occurrence of degeneration seem not to be determined (cf. LuBIŃsKA, 1975; KusAMA et al., 1975).

Honjin and Nakamura (1959) stated that the axons of large-sized myelinated fibers degenerate more rapidly than those of small-sized ones, and non-myelinated 


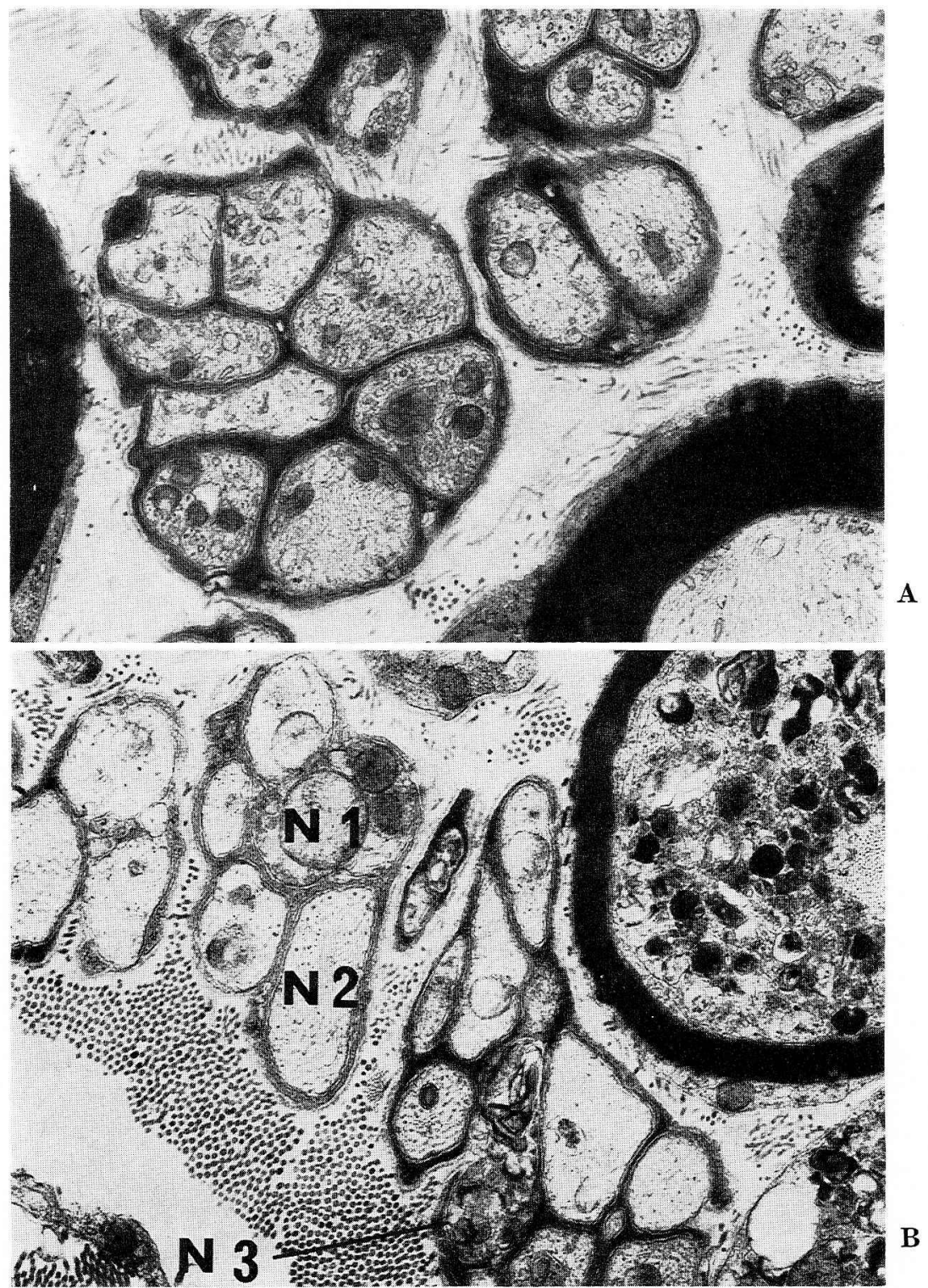

Fig. 8. Electron micrographs of non-myelinated fibers at $1 \mathrm{~mm}$ proximal (A) and distal (B) to a ligature at 1 day. A. The axons of fibers are moderately enlarged; their electron density is markedly increased due to increase of irregularly coursing neurofilaments and neurotubules, many kinds of vesicles, vacuoles and granules and mitochondria. The cytoplasm of the Schwann cell is markedly increased in density. $\times 15,000$. B. The axons show different appearances; some axons contain enlarged mitochondria devoid of clear cristae (N1), and some show irregularly coursing microtubules (N2) or irregular dense materials (N3). The axoplasm of neighboring large myelinated fiber shows an evident accumulation of dense granular materials. $\times 15,000$ 


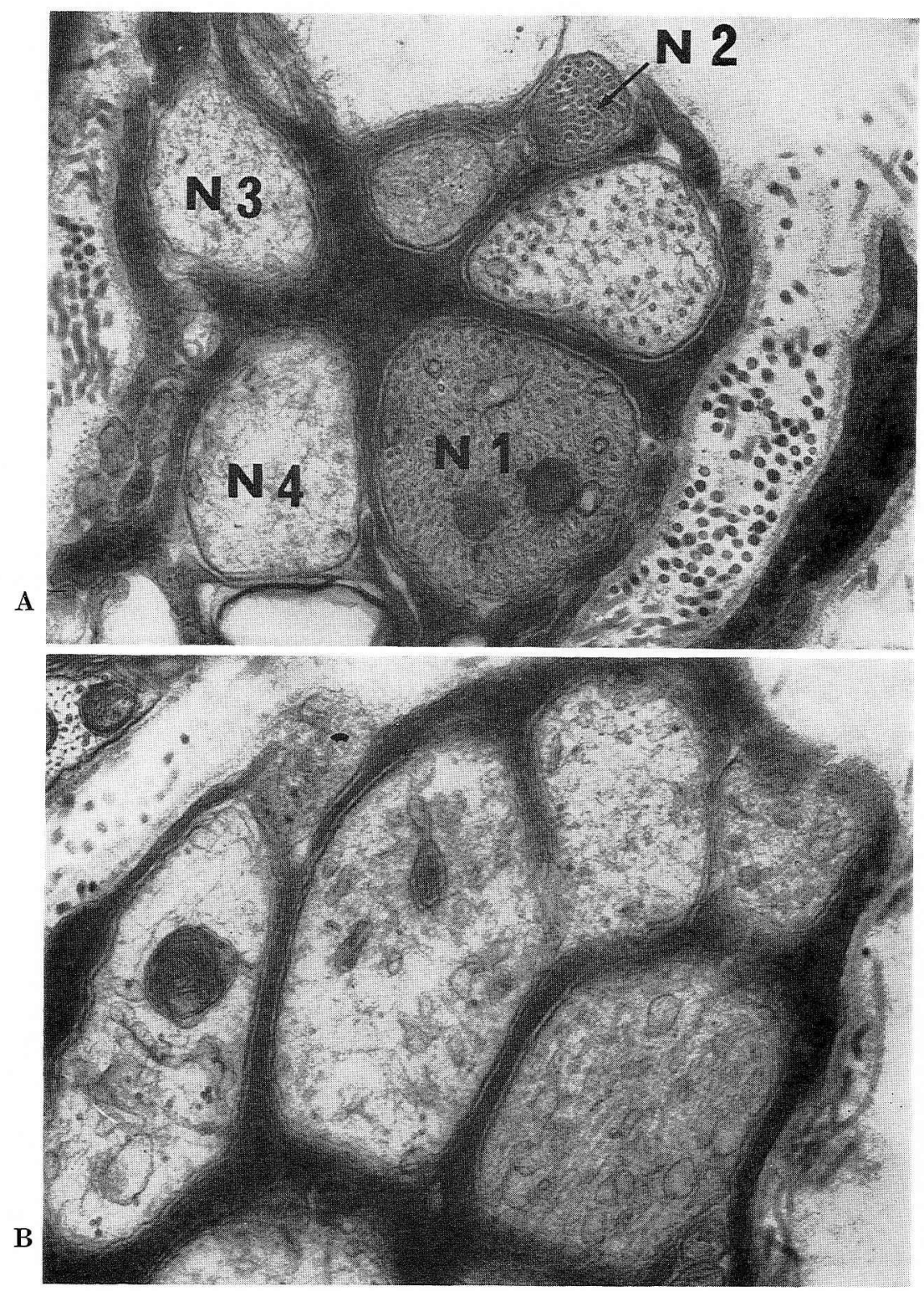

Fig. 9. Electron micrographs of non-myelinated nerve fibers at $1 \mathrm{~mm}$ proximal (A) and distal (B) to a ligature at 2 days. Some axons $(N 1, N 2)$ show a dense appearance due to increase in density of the matrix and increased numbers of microtubules. Some axons show amorphous or diffuse structure with moderate density $(N 3)$ or low density $(N 4)$. The Schwann cell contains dense cytoplasm. $\times 30,000$. B. The axoplasm of fibers contains many vacuoles and vesicles of varying shapes and sizes and irregularly coarsing microtubules. The Schwann cell cytoplasm shows increased electron density. $\times 30,000$ 
axons are most resistant among nerve axons. Our result generally supports HonjIN's observation. However, Oнмі (1961) reported that large-myelinated fibers are more resistant than the small-sized ones. LuBIŃsKa (1977) stated that the breakdown into ovoids (criterion of degeneration) of the nerve fibers occurs earlier in thin fibers than in thickest fibers.

The retrograde changes of nerve fibers are reported to occur in the limited segments adjacent to the lesion and to show accumulation of mitochondria and some enzymes (cf. Lubińska, 1975). In our experiment the myelinated fibers exhibit retrograde changes similar to the Wallerian degeneration, which are slighter in intensity and duration.

The morphological changes of non-myelinated fibers have already been studied light microscopically especially by CAJAL (1928). Electron microscopic findings of these changes are the main aims of the present study. Following ligation of the sciatic and other nerves, catecholamine-synthesizing enzymes (cf. NAGATSU, 1974) as well as noradrenaline (DAHLström, 1965; BlÜMCKe and Niedore, 1965; KAPELler and MAyoR, 1969; Olson, 1969; etc.) are accumulated in the proximal and distal stumps. By the electron microscopic study of a constricted sympathetic nerve, KAPELLER and MAYOR (1969) noticed accumulation of agranular vesicles in the distal segment of the ligature.

Despite careful observation we could not demonstrate the presence of granular vesicles in the proximal and distal stumps of non-myelinated fibers by ordinary fixation (glutaraldehyde-osmium). However, we noticed the increased density of axoplasm due to the increase in density of the matrix, and in the number of neurotubules and/or neurofilaments, mitochondria and vesicles. The increase in density of axoplasm together with the enlarged fiber size might correspond to the accumulation of axoplasm due to the blockade of axoplasmic flow.

The increase in number and density of neurotubules in some non-myelinated fibers is another morphological feature in the proximal segments of the ligature. If the neurotubules should be related to the axonal flow of catecholamines (cf. LuBińska, 1975; Nagatsu and Kondo, 1975), the fibers containing the dense accumulation of microtubules might be considered as catecholamine fibers, but they are devoid of granular vesicles. Therefore it is especially needed to investigate the presence of noradrenaline granules (granular vesicles) under the electron microscope with permanganate fixation or immunocytochemistry of tyrosine hydroxylase and dopamine $\beta$-hydroxylase.

Though the morphological changes observed in both the proximal and distal stumps of non-myelinated fibers are slight under this experimental condition, they are supposed to correspond to the morphological signs of accumulation of catecholamine synthesizing enzymes.

Acknowledgements. The authors wish to thank Dr. Genzo Isomura and Mr. Masahiro КокUво for their technical assistance. 


\title{
結禁によるラット坐骨神経の早期変化
}

\author{
永津郁子, 唐沢延幸, 清水信夫
}

先に私たちはラットとモルモットの坐骨神経結紮後, 早期にカテコールアミン生合成酵 素が結禁部位に蓄積することを, 免疫螢光法と酵素活性測定法により証明しているので, この早期の神経線維の形態変化を 光学および電子顕微鏡で 有髄神経線維と無髄神経線維 についてしらべた.

まず，結紮部位から $0.5 ， 1.0 \mathrm{~mm}$ 遠位および近位において 太い有髄神経に変化を認め たが, 細い有髄神経にはあまり变化が認められなかった。

無髄神経では軸索の基質が濃度を増し，細管ないし細線維の増加，いろいろの大きさの 小胞や空胞の増加が軸索の太くなるのにともなって認められた．これらの無䯣神経の变化 は, 結禁の中枢側により著明で, 酵素などの軸索内物質の蓄積によるものと考えられる.

\section{References}

Blümcke, S. and H. R. Niedore: Fluoreszenzmikroskopische und elektronenmikroskopische Untersuchungen an regenerierenden adrenergischen Nervenfasern. Z. Zellforsch. 68: 724-732 (1965).

Blümcke, S. and J. Rode: Axoplasmic alterations in the proximal and distal stumps of transsected nerves. Acta neuropathol. 7: 44-61 (1966).

Cajal, S. R. y.: Degeneration and regeneration of the nervous system. Oxford University Press, London, 1928.

Dahlström, A.: Observation on the accumulation of noradrenaline in the proximal and distal parts of peripheral adrenergic nerves after compression. J. Anat. 99: 677-689 (1965).

Fink, R. P. and L. Heimer: Two methods for selective silver impregnation of degenerating axons and their synaptic endings in the central nervous system. Brain Res. 4: 369-374 (1967).

Honjin, R. and T. Nakamura : Electron microscopy of peripheral nerve fibers III. On the axoplasmic changes during Wallerian degeneration. Okajimas Fol. anat. jap. 33: 131-156 (1959).

Kapeller, K. and D. Mayor: An electron microscopic study of the early changes distal to a constriction in sympathetic nerves. Proc. Roy. Soc. B. 172: 53-63 (1969).

Kusama, T., M. Fujii and E. Kawana: Morphology of nerve degeneration. In: (ed. by) T. Kusama and T. Nakazawa: Degeneration and regeneration in nervous system. (In Japanese). Igaku-Shoin, Tokyo, 1975 (p. 85-99).

Lee, J. C-Y. : Electron microscopy of Wallerian degeneration. J. comp. Neurol. 120: 65-79 (1963).

Lubińska, L.: On axoplasmic flow. Int. Rev. Neurobiol. 17: 241-296 (1975).

: Early course of Wallerian degeneration in myelinated fibers of the rat phrenic nerve. Brain Res. 130: 47-63 (1977).

Nagatsu, I. : Axoplasmic flow. (In Japanese). Prog. Nerve Res. 18: 52-66 (1974).

Nagatsu, I., B. K. Hartman and S. Udenfriend: The anatomical characteristics of dopamine$\beta$-hydroxylase accumulation in ligated sciatic nerve. J. Histochem. Cytochem. 22: 1010-1018 (1974).

Nagatsu, I. and Y. Kondo: Studies on axonal flow of dopamine $\beta$-hydroxylase and tyrosine hydroxylase in sciatic nerves by immunofluorescent and biochemical methods. Acta histochem. cytochem. 8: 279-287 (1975). 
Nagatsu, I., Y. Kondo, S. Inagaki, N. Karasawa, T. Kato and T. Nagatsu : Immunofluorescent studies on tyrosine hydroxylase: Application for its axoplasmic transport. Acta histochem. cytochem. 10: 494-499 (1977).

Nathaniel, E. J. H. and D. C. Pease: Degenerative changes in rat dorsal roots during Wallerian degeneration. J. Ultrastr. Res. 9: 511-532 (1963).

Nauta, W. J. H. and P. A. Gygax: Silver impregnation of degenerating axons in the central nervous system: A modified technic. Stain Tech. 29: 91-93 (1954).

O'Daly, J. A. and T. Imaeda : Electron microscopic study of Wallerian degeneration in cutaneous nerves caused by mechanical injury. Lab. Invest. 17: 744-766 (1967).

Ohmi, S.: Electron microscopic study on Wallerian degeneration of the peripheral nerve. Z. Zellforsch. 54: 39-67 (1961).

Olson, L.: Intact and regenerating sympathetic noradrenaline axons in the rat sciatic nerve. Histochemie 17: 349-367 (1969).

永津 郁子

厂470-11 豊明市沓掛町田楽厅窪 1-98

名古屋保健衛生大学医学部

解剖学教室
Prof. Ikuko Nagatsu

Department of Anatomy

Fujita-Gakuen University School of Medicine

Toyoake, Aichi

470-11 Japan 